\title{
Biological evaluation of rapeseed meal, soya-bean meal and casein fed to the weanling and the mature rat
}

\author{
N. J. DROULISCOS AND J. P. BOWLAND \\ Department of Animal Science, The University of Alberta, \\ Edmonton, Alberta, Canada
}

(Received 6 June I968-Accepted 2 August I968)

I. The biological evaluation of solvent and prepress-solvent processed rapeseed meals RM(S) and RM(PS) was carried out with the weanling (phase I) and the mature (phase $z$ ) rat. The nutritional indices measured were compared with those for diets containing soyabean meal SM and casein CS.

2. The true nitrogen digestibility ( $(\mathrm{dd}(\mathrm{N}))$ for $\mathrm{RM}(\mathrm{S}), \mathrm{RM}(\mathrm{PS}), \mathrm{SM}$ and $\mathrm{CS}$ in the weanling rat was $(\%) 78 \cdot 9 \pm I \cdot 2,77 \cdot 9 \pm 2 \cdot 7,90.4 \pm 0.9$ and $96.0 \pm 0.6(P<0.01)$ respectively. Net protein utilization was $(\%) 68.9 \pm \mathrm{IO} \cdot \mathrm{I}, 65 \cdot 6 \pm 3.5,80 \cdot 6 \pm 4 \cdot \overline{8}$ and $8 \mathrm{I} \cdot 7 \pm 3 . \mathrm{I}(P<0.05)$ respectively. Biological value was $(\%) 83^{\circ} \circ \pm 7^{\circ} \cdot, 84^{\prime} \cdot 1 \pm 5^{\circ} 6,89^{\circ} \circ \pm 5^{\cdot} \mathrm{I}$ and $85^{\circ} \circ \pm 3^{\circ} 4(P<0 \cdot 05)$ respectively. The same indices when measured in the mature rat showed an increase over those obtained in the weanling rat.

3. The growth-promoting effects of the test diets were evaluated over a period of 8 weeks with $a d l i b$. feeding between phases $I$ and 2. Protein efficiency ratio averaged $2 \cdot 0 \pm 0.14$, $I .9 \pm 0.35,2.4 \pm 0.39$ and $2.3 \pm 0.25$ for the RM(S), RM(PS), SM and CS treatments respectively.

4. The daily endogenous urinary $\mathrm{N}$ excretion was $\mathrm{r} \cdot 58 \pm 0.14 \mathrm{mg} \mathrm{N} / \mathrm{basal} \mathrm{kcal}$ or $254 \mathrm{mg}$ $\mathrm{N} / \mathrm{kg}$ body-weight for the weanling rat and $0.16 \mathrm{mg} \mathrm{N} / \mathrm{basal} \mathrm{kcal}$ or $18 \mathrm{mg} \mathrm{N} / \mathrm{kg}$ bodyweight for the mature rat. Metabolic faecal $\mathrm{N}$ excretion was $98 \cdot 0 \pm 9 \cdot 3 \mathrm{mg} \mathrm{N} / \mathrm{kg}$ body-weight, or $27.9 \%$ of the total $\mathrm{N}$ output for the weanling rat, and $37.9 \pm 7.2 \mathrm{mg} \mathrm{N} / \mathrm{kg}$ body-weight, or $67.3 \%$ of the total $\mathrm{N}$ output for the mature rat during the 'protein-free' feeding periods.

5. The fresh weight of the thyroid gland per $\mathrm{kg}$ metabolic body size was $70,90,40$ and $40 \mathrm{mg}$ respectively for the RM(S), RM(PS), SM and CS dietary treatments.

6. The moisture content of the carcasses was $66 \cdot 9 \pm 3 \cdot 1,63 \cdot 6 \pm 2 \cdot 3$ and $64 \cdot 2 \pm 2 \cdot 2$ and the protein content on a dry-matter basis was $55^{\circ} 9 \pm 9 \cdot 6,50 \cdot 2 \pm 6.4$ and $53.1 \pm 4.9$ for the RM (S and PS), SM and CS diets respectively. The results suggest an increased lean body mass in the rats receiving the rapeseed meal treatments.

7. Under the conditions of this experiment solvent-extracted rapeseed meal was superior to prepress-solvent meal on the basis of rat growth response and of results for nutritional indices. Both rapeseed meals were inferior to soya-bean meal and casein.

Experimental work conducted in Canada and abroad on the utilization of rapeseed meal as a protein supplement has been reviewed (Bowland, Clandinin \& Wetter, 1965). Information on the biological evaluation of rapeseed meal is limited and the authors of the present report are not aware of such work done with the weanling and the mature rat. Although the protein of rapeseed meal is reasonably well balanced in essential amino acids, the method of processing, the high crude fibre content $(9-15 \%)$, the level of goitrogenic compounds and the bitter taste of the meal may affect its value as a protein supplement.

Experiments have been conducted in which solvent extracted soya-bean meal and vitamin-free casein served as controls for the biological evaluation of solvent or prepress-solvent processed rapeseed meals.

The results obtained in this investigation have disclosed variations in the endogenous 
urinary nitrogen $\mathrm{e}(\mathrm{N})$ and metabolic faecal nitrogen $\mathrm{m}(\mathrm{N})$ excretion of the weanling and the mature rat. The biological value (BV) and net protein utilization (NPU) of the diet are discussed in relation to the growth response of the rats.

\section{EXPERIMENTAL}

Three-week-old weanling rats of the Sprague-Dawley strain weighing between 37 and $40 \mathrm{~g}$ were used. They were allocated to four diets, each group including two male and two female rats. Measurements of $\mathrm{BV}$ were made on all rats immediately after weaning (phase I) and at maturity (phase 2 ). An additional eight mature female rats were used to determine the $\mathrm{BV}$ in the second phase (phase $2 A$ ) of the experiment only.

Table I. Ingredients $(\mathrm{g} / \mathrm{1} \mathrm{\circ} \mathrm{g})$ and composition of the protein-free diets, test diets and of rapeseed meal

\begin{tabular}{|c|c|c|c|c|c|c|c|c|c|}
\hline & \multicolumn{3}{|c|}{ Protein-free diets } & \multicolumn{4}{|c|}{ Test diets } & \multicolumn{2}{|c|}{$\begin{array}{l}\text { Rapeseed meal } \\
\text { (by analysis) }\end{array}$} \\
\hline & $\mathbf{r}$ & 2 & 3 & $\mathrm{RM}(\mathrm{S})$ & $\mathrm{RM}(\mathrm{PS})$ & $\mathrm{SM}$ & $\mathrm{CS}$ & $\mathrm{S}$ & PS \\
\hline \multicolumn{10}{|c|}{ Ingredient } \\
\hline Maize starch & 59 & 58 & 56 & 32 & 32 & 38 & 48 & 一 & - \\
\hline Sucrose & 30 & 29 & 29 & 30 & 30 & 30 & 30 & - & - \\
\hline Cellulose & 一 & 2 & 4 & - & - & 一 & - & - & - \\
\hline Maize oil & 5 & 5 & 5 & 5 & 5 & 5 & 5 & 一 & - \\
\hline $\begin{array}{l}\text { Soya-bean meal } \\
\text { (solvent) }\end{array}$ & - & - & - & 一 & - & 21 & - & - & - \\
\hline $\begin{array}{l}\text { Rapeseed meal } \\
\text { (solvent) }\end{array}$ & - & $\ldots$ & - & 27 & - & - & 一 & - & 一 \\
\hline $\begin{array}{l}\text { Rapeseed meal } \\
\quad \text { (prepress-solvent) }\end{array}$ & 一 & $一$ & - & 一 & 27 & 一 & - & - & — \\
\hline $\begin{array}{l}\text { Casein } \\
\quad \text { (vitamin-free) }\end{array}$ & - & - & -- & - & - & - & II & - & - \\
\hline Mineral mix * & 4 & 4 & 4 & 4 & 4 & 4 & 4 & $\ldots$ & - \\
\hline Vitamin mix $\dagger$ & & & & & & & & & \\
\hline (a) & I & $\mathbf{I}$ & I & $\mathbf{I}$ & I & $\mathbf{I}$ & I & - & - \\
\hline (b) & I & $\mathbf{I}$ & I & $\mathbf{I}$ & I & $\mathbf{I}$ & $I$ & - & - \\
\hline \multicolumn{10}{|c|}{ Composition } \\
\hline $\begin{array}{l}\text { Dry matter } \\
\quad \text { (by analysis) }(\%)\end{array}$ & $93 \cdot 9$ & $93 \cdot 9$ & $94^{\prime} \mathbf{I}$ & 94.5 & $94^{\circ} 5$ & $94 \cdot 2$ & $94^{\circ} \circ$ & - & - \\
\hline $\begin{array}{l}\text { Crude protein } \\
\text { (by analysis) (\%) }\end{array}$ & 0.24 & 0.24 & 0.24 & 10.4 & 10.2 & $9 \cdot 6$ & $9 \cdot 9$ & - & 一 \\
\hline $\begin{array}{l}\text { Crude fibre } \\
\quad \text { (estimated) }(\%)\end{array}$ & $\circ$ & $2 \cdot 0$ & $4 \cdot 0$ & 4.0 & $4 \cdot 0$ & 2.0 & $\circ$ & $\cdots$ & 一 \\
\hline $\begin{array}{l}\text { Gross energy } \\
\quad \text { (by analysis) (kcal/1) }\end{array}$ & $\begin{array}{l}3673 \\
(\mathrm{~kg})\end{array}$ & 3847 & 3760 & $3^{864}$ & 3857 & 3762 & 4074 & - & - \\
\hline $\begin{array}{l}\text { Oxazolidinethione } \\
(\mathrm{mg} / \mathrm{g})\end{array}$ & - & - & 一 & 一 & 一 & - & - & $2 \cdot 79$ & 3.08 \\
\hline $\begin{array}{l}\text { Isothiocyanate } \\
(\mathrm{mg} / \mathrm{g})\end{array}$ & - & - & 一 & - & - & - & - & $3 \cdot 78$ & 4.24 \\
\hline \multicolumn{10}{|c|}{ 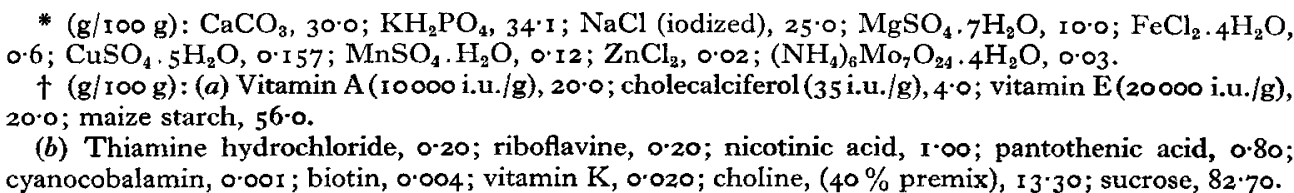 } \\
\hline
\end{tabular}


These additional rats were added in order that any differences in BV and other nutritional indices determined at maturity in the rats previously fed diets containing rapeseed meal, soya-bean meal or casein $v$. those reared with regular stock diet could be detected. The composition of the protein-free and test diets is shown in Table 1 . The amino acid requirements of the rat for growth and dietary levels of these amino acids are given in Table 2. The rapeseed meals used in this study were obtained by the solvent extraction, or prepress-solvent extraction, procedures described by Youngs (Bowland et al. 1965).

Table 2. Minimum amino acid requirements for growth in the rat and approximate amounts of amino acids provided in the test diets

(mg/rog food, air-dry basis)

\begin{tabular}{|c|c|c|c|c|c|}
\hline \multirow[b]{2}{*}{ Amino acid } & \multirow{2}{*}{$\begin{array}{l}\text { For } \\
\text { growth* }\end{array}$} & \multicolumn{4}{|c|}{ Test diets } \\
\hline & & $\mathrm{RM}(\mathrm{S}) \dagger$ & RM(PS)† & SM $\ddagger$ & CSt \\
\hline L-Lysine & 90 & 59 & 59 & 62 & 87 \\
\hline L-Methionine & 60 & $18(30)$ & $19(3 \mathrm{I})$ & $18(33)$ & $23(27)$ \\
\hline L-Cystine & 一 & 12 & 12 & 15 & 4 \\
\hline L-Phenylalanine & 90 & $39(62)$ & $38(6 \mathrm{I})$ & $49(79)$ & $59(89)$ \\
\hline L-Tyrosine & - & 23 & 23 & 32 & 63 \\
\hline L-Histidine & 30 & 27 & 26 & 25 & $3 I$ \\
\hline L-Isoleucine & 50 & 38 & 39 & $5^{6}$ & 66 \\
\hline L-Leucine & 80 & 69 & 70 & 76 & 108 \\
\hline L-Valine & 70 & 49 & 50 & 53 & 73 \\
\hline L-Arginine & - & 56 & 57 & 60 & 39 \\
\hline L-Tryptophan & 15 & 12 & 13 & I 2 & 12 \\
\hline L-Threonine & 50 & 44 & 44 & 37 & 44 \\
\hline
\end{tabular}

Values in parentheses for phenylalanine and methionine include an adjustment for tyrosine and cystine, respectively. $I / 3$ phenylalanine may be supplied by L-tyrosine, $1 / 3-1 / 2$ methionine may be supplied by L-cystine.

* National Research Council (1962).

+ Clandinin $(1967)$.

$\ddagger$ Block \& Weiss (1956).

The rats were housed individually in metal metabolism cages with an adjustable food trough to minimize food wastage. An extra fine, 6 mesh per $\mathrm{cm}$, screen was attached under the standard wire screen of the faeces collection pan to ensure the separation of the small faeces from the urine. The assigned protein-free and experimental diets as well as water were offered $a d l i b$. No food wastage or gross food contamination was experienced.

'The BV of the four diets was measured by the $\mathrm{N}$ balance technique (Mitchell, 1924) on four weanling rats (two males and two females) at 3 weeks of age and again at I 2 weeks of age. Because of the different fibre contents of the diets, three protein-free diets containing 0,2 or $4 \%$ cellulose were fed. The rats were fed the protein-free diets for a 4-day collection period preceded by a period of diet adaptation of $5-7$ days. Reports vary as to the time required by an animal to reach the level of a relatively constant, but minimum, urinary $\mathrm{N}$ excretion with protein-free diets (Allison 8 Wannemacher, 1965; Blaxter \& Wood, 1951 $a$; Fomon, DeMaeyer \& Owen 1965; Munro, I964; Young \& Scrimshaw, 1968). The length of the preliminary period was 


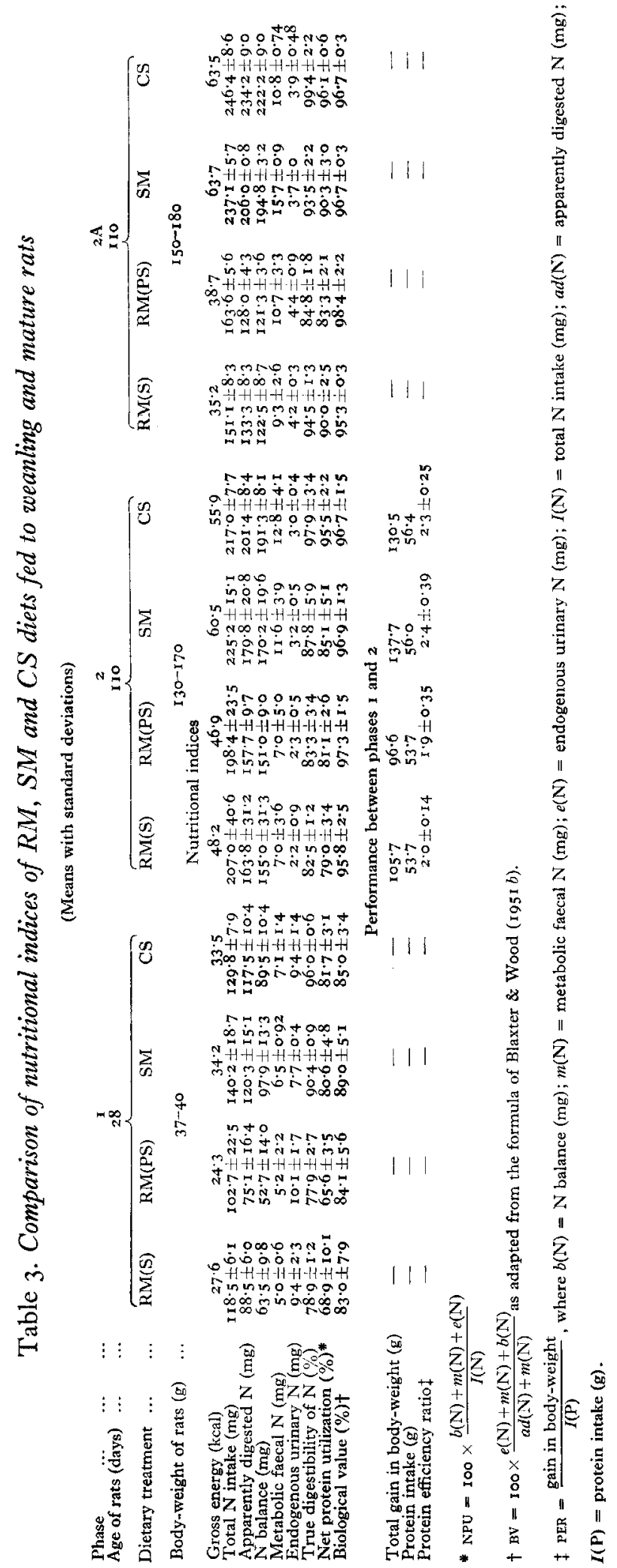


arbitrarily chosen on the basis of the upper values for urinary excretion found in the previous studies.

Measurements in the test period were not made until the loss of body-weight, which occurred with the protein-free diets, had been made good. On completion of the recovery period, each rat was offered $a d$ lib. for an 8-week period the test diet received in phase $\mathrm{I}$. The calculation of the protein efficiency ratio (PER) was based on principles suggested by Boas-Fixsen (1935) and Campbell (I96I). Phases 2 and $2 \mathrm{~A}$ followed, using the same procedures as in phase $\mathrm{I}$, and upon their completion all the rats were killed with chloroform. The thyroid gland was removed, its fresh weight recorded and the entire carcass was dried, ground and analysed for moisture and crude protein content.

The total $\mathrm{N}$ contents of diets, carcasses, faeces and urine were determined by the macroKjeldahl method. The dry-matter content of carcasses and faeces were determined using a 'Thermovac' freeze dryer. The samples were allowed to dry for $48 \mathrm{~h}$ at a temperature of $-60^{\circ}$ and a vacuum of $7.7 \mu \mathrm{m}$ mercury $/ \mathrm{cm}^{2}$.

The oxazolidinethione and isothiocyanate contents of the rapeseed meals were determined by the methods of Astwood, Greer \& Ettlinger (1949) and Wetter (1955). Statistical analysis was carried out with an IBM $360-67$ electronic computer at the University of Alberta.

\section{RESULTS}

Table 3 summarizes the results for each nutritional index. In phase $\mathbf{I}, \mathbf{N}$ intake was minimal with weanling rats receiving the RM(PS) diet (102.7 $\pm 22 \cdot 5)$ followed by those having the RM(S) diet (II $8 \cdot 5 \pm 6 \cdot 1$ ), the CS diet (I29.8 $\pm 7 \cdot 9$ ) and the SM diet $(140 \cdot 2 \pm 18 \cdot 7)$. In phase 2 , with mature rats, $\mathrm{N}$ intake increased but, with the $\mathrm{SM}$ and CS diets it remained above the RM diets. Apparently digested $\mathrm{N}(\operatorname{ad}(\mathrm{N}))$ averaged

Table 4. Faecal nitrogen and urinary $N$ excretion $(m g / k g$ body-weight per day) in rats while receiving the protein-free and the test diets

(Means for four rats in phases 1,2 and $2 A$ )

Protein-free diets

\begin{tabular}{|c|c|c|c|c|c|c|c|c|c|c|c|c|}
\hline Phase & & 3 & 3 & 2 & I & Mean & & $\mathrm{RM}(\mathrm{S})$ & $\mathrm{RM}(\mathrm{PS})$ & $\mathrm{SM}$ & $\mathrm{CS}$ & Mean \\
\hline I & $\begin{array}{l}\mathrm{m}(\mathrm{N}) \\
\mathrm{e}(\mathrm{N})\end{array}$ & $\begin{array}{r}90 \cdot 1 \\
257 \cdot 0\end{array}$ & $\begin{array}{r}98 \cdot 0 \\
285 \cdot 0\end{array}$ & $\begin{array}{r}92.4 \\
213.0\end{array}$ & $\begin{array}{l}\text { III I I I } \\
26 I \cdot 0\end{array}$ & $\begin{array}{r}98.0 \\
254.0\end{array}$ & $\begin{array}{l}\text { FN } \\
\text { UN }\end{array}$ & $\begin{array}{l}554^{\circ} 0 \\
462 \cdot 0\end{array}$ & $\begin{array}{l}552 \cdot 0 \\
448.0\end{array}$ & $\begin{array}{l}367 \cdot 0 \\
415 \cdot 0\end{array}$ & $\begin{array}{l}225^{\circ} \\
517.0\end{array}$ & $\begin{array}{l}424 \cdot 0 \\
460 \cdot 0\end{array}$ \\
\hline 2 & $\begin{array}{l}m(N) \\
e(N)\end{array}$ & $\begin{array}{l}30.3 \\
15.3\end{array}$ & $\begin{array}{l}37.3 \\
17.5\end{array}$ & $\begin{array}{l}34.3 \\
18 \cdot 9\end{array}$ & $\begin{array}{l}49 \cdot 5 \\
18 \cdot 3\end{array}$ & $\begin{array}{l}37 \cdot 9 \\
18 \cdot 0\end{array}$ & $\begin{array}{l}\text { FN } \\
\mathrm{UN}\end{array}$ & $\begin{array}{r}267 \cdot 6 \\
54.5\end{array}$ & $\begin{array}{r}268 \cdot 4 \\
43 \cdot 5\end{array}$ & $\begin{array}{r}200 \cdot 3 \\
53 \cdot 0\end{array}$ & $\begin{array}{l}84 \cdot 1 \\
55 \cdot 1\end{array}$ & $\begin{array}{r}205^{\circ} 0 \\
51 \cdot 5\end{array}$ \\
\hline $2 A$ & $\begin{array}{l}\mathrm{m}(\mathrm{N}) \\
\mathrm{e}(\mathrm{N})\end{array}$ & $\begin{array}{l}55^{\circ} 3 \\
24^{\circ} 0\end{array}$ & $\begin{array}{l}64 \cdot 6 \\
29 \cdot 3\end{array}$ & $\begin{array}{l}55.6 \\
22 \cdot 5\end{array}$ & $\begin{array}{l}48 \cdot 7 \\
23 \cdot 7\end{array}$ & $\begin{array}{l}56 \cdot I \\
25 \cdot 0\end{array}$ & $\begin{array}{l}\text { FN } \\
\text { UN }\end{array}$ & $\begin{array}{r}105^{\prime} I \\
64^{\prime} I\end{array}$ & $\begin{array}{r}238 \cdot 9 \\
45 \cdot 0\end{array}$ & $\begin{array}{r}67.9 \\
59.9\end{array}$ & $\begin{array}{l}65 \cdot 9 \\
64 \cdot 8\end{array}$ & $\begin{array}{r}144.5 \\
58.5\end{array}$ \\
\hline
\end{tabular}

$\mathrm{m}(\mathrm{N})=$ metabolic faecal $\mathrm{N} ; \mathrm{e}(\mathrm{N})=$ endogenous urinary $\mathrm{N} ; \mathrm{FN}=$ total faecal nitrogen; $\mathrm{UN}=$ total urinary nitrogen.

120.3 and $I 17.5 \mathrm{mg} \mathrm{N} /$ day for rats receiving the SM or CS diets but only 88.5 and $75^{\circ} \mathrm{I} \mathrm{mg}$ for rats receiving the RM diets in phase $\mathrm{I}$. These relative differences remained in phases 2 and $2 \mathrm{~A}$. Although only female rats were used in phase $2 \mathrm{~A}$, no sex interactions were detected in the results, direct comparisons may, therefore, be made between phases 2 and $2 A$. 
The $\mathrm{m}(\mathrm{N})$ excreted was $98 \cdot 0 \pm 9.3 \mathrm{mg} / \mathrm{kg}$ body-weight (Table 4 ) for the weanling rat and $37.9 \pm 7.2 \mathrm{mg} \mathrm{N} / \mathrm{kg}$ body-weight at maturity. No significant differences appeared in the faecal $\mathrm{N}$ excretion during the protein-free period between diets no. I, 2 and 3 , which contained o, 2 and $4 \%$ cellulose respectively.

The true $\mathrm{N}$ digestibility $(\mathrm{td}(\mathrm{N}))$ varied between dietary treatments. For example, in phase $\mathrm{x}, 90^{\circ} 4$ and $96.0 \% \mathrm{~N}$ was digested for SM and CS diets, respectively, and 78.9 and $77.9 \%$ for rats receiving the RM diets (Table 3 ).

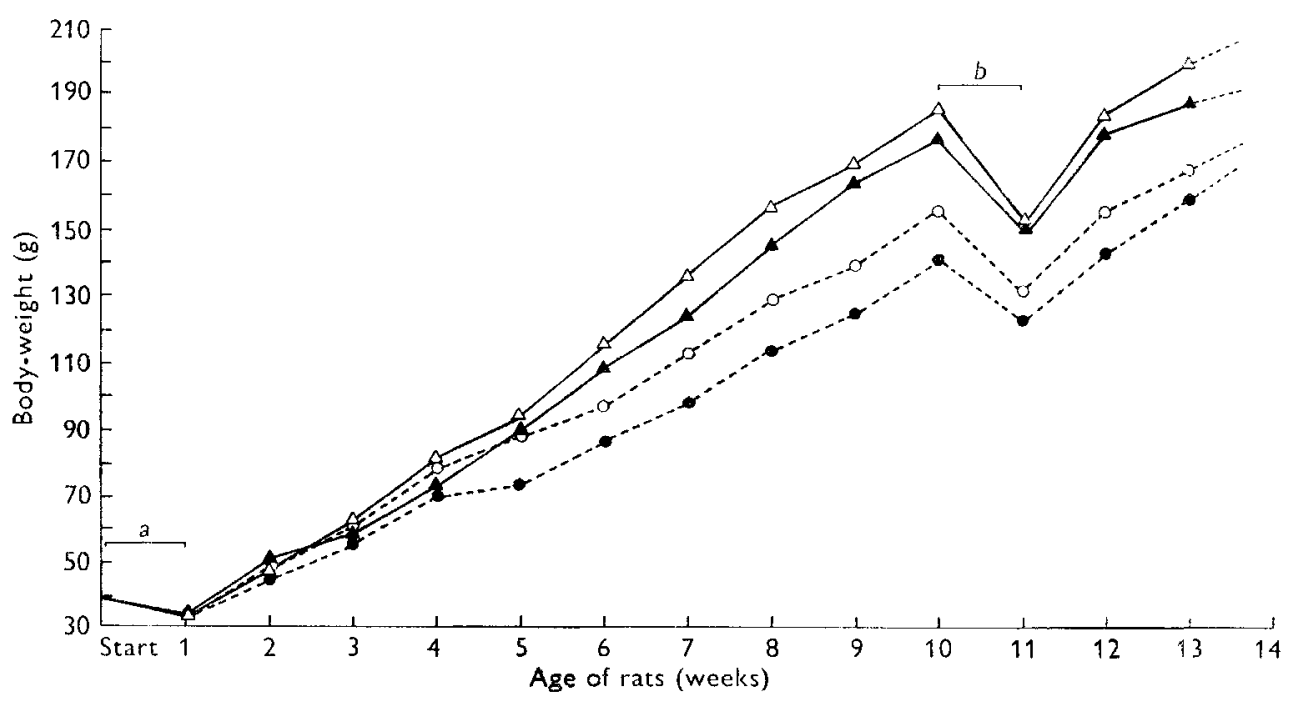

Fig. I. Body-weight (g) gains of rats from weaning to maturity. The periods of protein-free feeding are indicated by $a$ and $b$ on the curve. $\triangle-\triangle, S M$ diet; $\Delta-\Delta$, CS diet; $O-O$, RM(S) diet; - - RM(PS) diet.

The $e(N)$ excretion during the protein-free period averaged $1 \cdot 5^{8} \pm 0 \cdot 14 \mathrm{mg} \mathrm{N} /$ basal kcal for the weanling rat and dropped to between 0.16 and $0.25 \mathrm{mg} \mathrm{N} / \mathrm{basal} \mathrm{kcal}$ at maturity. Expressed as $\mathrm{mg} \mathrm{N} / \mathrm{kg}$ body-weight per day, the values ranged from 15.3 to $29.3 \mathrm{mg} / \mathrm{kg}$ for the mature and $213^{-28} \mathrm{mg} / \mathrm{kg}$ for the weanling rat (Table 4 ). The high values for the $\mathrm{m}(\mathrm{N})$ excretion, which averaged $98.0 \mathrm{mg} \mathrm{N} / \mathrm{kg}$ body-weight per day in the weanling rat, were also reduced at maturity (Table 4 ). Values for $\mathrm{N}$ balance $(b(N))$ followed the same pattern as those for apparent or true $\mathrm{N}$ digestibility.

In phase $\mathrm{I}$, values for $\operatorname{td}(\mathrm{N})$, NPU and BV were higher for the SM and CS diets than for the RM diets (Table 3 ). Average values for $\operatorname{td}(\mathrm{N})$, NPU and BV were $78.4,90^{\circ} 4$ and $96 \cdot 0 ; 67 \cdot 2,80 \cdot 6$ and $8 \mathrm{r} \cdot 7$; and $83 \cdot 6,89 \cdot 0$ and $85 \cdot 0 \%$ for the RM (combined) SM and CS diets respectively. In phase 2 and for the same sequential order as above these values were $82 \cdot 9,87.8$ and $97 \cdot 9 ; 80 \cdot 0,85^{\circ} \mathrm{I}$ and $95 \cdot 5$; and $96 \cdot 6,96 \cdot 9$ and $96 \cdot 7 \%$ respectively. The differences between treatments in phase 2 were less than those in phase 1 . 'The additional mature rats in phase $2 \mathrm{~A}$ had $\operatorname{td}(\mathrm{N})$, NPU and $\mathrm{BV}$ in a similar range to those in phase 2 .

Body-weight gain and gross energy intake per rat per day were in descending order for treatments SM, CS, RM(S) and RM(PS) (Table 3). Growth response over the 
entire experimental period is shown diagrammatically in Fig. I. Each treatment is represented by the pooled average for two male and two female rats.

Values for NPU and BV reflected the poorer growth of the rats fed diet RS, but NPU gave a closer indication of performance. In phase I, the NPU values for SM, CS and the two RM diets were $80 \cdot 6,8 \mathrm{r} \cdot 7$ and $67 \cdot 2 \%$, respectively. The BV for the same diets was

Table 5. Metabolic body size (MBS) of rats, weight of thyroid gland (Th) and ratio of $T h$ to $M B S$

\begin{tabular}{|c|c|c|c|c|}
\hline Diet & $\mathrm{RM}(\mathrm{S})$ & RM(PS) & SM & CS \\
\hline \multicolumn{5}{|c|}{ Metabolic body size (g) } \\
\hline $\begin{aligned} \text { Phase } & 2^{*} \\
& 2 A \dagger\end{aligned}$ & $\begin{array}{l}260 \\
258\end{array}$ & $\begin{array}{l}276 \\
245\end{array}$ & $\begin{array}{l}299 \\
289\end{array}$ & $\begin{array}{l}289 \\
287\end{array}$ \\
\hline Mean $\ddagger$ & $259 \pm I \cdot 0$ & $260 \pm 19.2$ & $294 \pm 5 \cdot 0$ & $288 \pm \pi \cdot 0$ \\
\hline \multicolumn{5}{|c|}{ Thyroid gland (mg) } \\
\hline Phase $2 *$ & $19 \cdot 8$ & $24 \cdot 3$ & $12 \cdot 4$ & $12 \cdot 2$ \\
\hline${ }_{2} A \dagger$ & $12 \cdot 5$ & $22 \cdot 3$ & II'I & 13.2 \\
\hline Mean $\downarrow$ & $17 \cdot 4 \pm 3 \cdot 5$ & $23 \cdot 6 \pm 4 \cdot 9$ & $12 \cdot 0 \pm 1 \cdot 9$ & $12 \cdot 5 \pm 1 \cdot 4$ \\
\hline \multicolumn{5}{|c|}{ Th (mg)/kg MBS } \\
\hline Phase $2^{*}$ & 80 & 90 & 40 & 40 \\
\hline $2 A \dagger$ & 60 & 90 & 40 & 40 \\
\hline Mean & 70 & 90 & 40 & 40 \\
\hline \multicolumn{5}{|c|}{$\begin{array}{l}\text { * Mean for four rats. } \\
+ \text { Mean for two rats. } \\
\ddagger \text { Mean with standard deviation. }\end{array}$} \\
\hline
\end{tabular}

Table 6. Moisture $\left(\mathrm{H}_{2} \mathrm{O}\right)$ and crude protein $(\mathrm{CP})$ contents of rat carcasses and ratio, $\mathrm{H}_{2} \mathrm{O}: \mathrm{CP}$

\begin{tabular}{|c|c|c|c|c|}
\hline Diet & $\operatorname{RM}(S)$ & $\mathrm{RM}(\mathrm{PS})$ & $\mathrm{SM}$ & CS \\
\hline \multicolumn{5}{|c|}{ Moisture ( $\mathrm{g} / \mathrm{r}$ oo g carcass) } \\
\hline $\begin{array}{r}\text { Phase } 2 \\
2 \mathrm{~A}\end{array}$ & $\begin{array}{l}63 \cdot 2 \\
7 I \cdot 6\end{array}$ & $\begin{array}{l}64 \cdot 5 \\
67 \cdot 3\end{array}$ & $\begin{array}{l}62 \cdot 2 \\
65 \cdot 1\end{array}$ & $\begin{array}{l}62 \cdot 9 \\
65 \cdot 6\end{array}$ \\
\hline Mean* & $67 \cdot 4 \pm 4 \cdot 1$ & $66 \cdot 3 \pm 2 \cdot 1$ & $63 \cdot 6 \pm 2 \cdot 3$ & $64 \cdot 2 \pm 2 \cdot 2$ \\
\hline \multicolumn{5}{|c|}{ Protein (g/roo g dry carcass) } \\
\hline Phase 2 & $49 \cdot 2$ & $52 \cdot 8$ & $50 \cdot 0$ & $50 \cdot 0$ \\
\hline $2 A$ & $73 \cdot 4$ & $58 \cdot 0$ & $50 \cdot 5$ & $59 \cdot 2$ \\
\hline Mean* & $57 \cdot 2 \pm 12 \cdot 0$ & $54 \cdot 5 \pm 7 \cdot 2$ & $50 \cdot 2 \pm 6 \cdot 4$ & $53 \cdot 1 \pm 4 \cdot 9$ \\
\hline \multicolumn{5}{|c|}{ Ratio, $\mathrm{H}_{2} \mathrm{O}: \mathrm{CP}$} \\
\hline $\begin{array}{r}\text { Phase } 2 \\
2 \mathrm{~A}\end{array}$ & $\begin{array}{l}\text { I.28 } \\
0.98\end{array}$ & $\begin{array}{l}I \cdot 24 \\
I \cdot I 6\end{array}$ & $\begin{array}{l}I \cdot 24 \\
I \cdot 29\end{array}$ & $\begin{array}{l}\mathrm{I} \cdot 26 \\
\mathrm{I} \cdot \mathrm{I} I\end{array}$ \\
\hline Mean & $\mathrm{I} \cdot \mathrm{I} 8$ & $I \cdot 22$ & I. 27 & $I \cdot \mathbf{2 I}$ \\
\hline
\end{tabular}

$89^{\circ} \circ, 85^{\circ} 0$ and 83.5 while weight gain, taking SM as 100 , was $95^{\circ} 3$ for $\mathrm{CS}$ and $73^{\circ} 8$ for the average of the two RM. The PER for the RM(S) and RM(PS) diets was $2 \cdot 0 \pm 0.14$ and $I \cdot 9 \pm 0.35$ v. $2 \cdot 4 \pm 0.39$ and $2 \cdot 3 \pm 0.25$ for the SM and CS diets respectively.

The fresh weights of the thyroid averaged $12 \cdot 0-12 \cdot 5 \mathrm{mg}$ for the rats fed the SM and

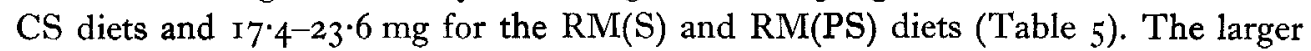
thyroid glands observed in the RM(PS) treatment are in accordance with the higher 
oxazolidinethione and isothiocyanate content of the prepress-solvent RM. The thyroid weights were expressed on a kg MBS basis, and values in the order of $70,9 \circ, 4^{\circ}$ and $4^{\circ}$ were obtained for the RM(S) RM(PS), SM and CS treatments respectively.

Table 6 summarizes the results of the carcass analyses. The percentage mean values with standard deviations for the moisture content were $66 \cdot 9 \pm 3^{\cdot I}$ for the RM(S and PS combined), $63 \cdot 6 \pm 2 \cdot 3$ for the SM and $64 \cdot 2 \pm 2 \cdot 2$ for the CS treatments. The crude protein (CP) content on a dry-matter basis was $55^{\cdot} 9 \pm 9 \cdot 6$ for RM, $5^{\circ} \cdot 2 \pm 6 \cdot 4$ for SM and $53^{\cdot} \pm 4.9$ for the $\mathrm{CS}$ treatments. The ratio of $\mathrm{H}_{2} \mathrm{O}$ : $\mathrm{CP}$ was quite constant for rats from phase 2, but fluctuated for rats from phase $2 \mathrm{~A}$.

\section{DISCUSSION}

True $N$ digestibility, NPU, BV, PER and growth

The daily food, $\mathrm{N}$ and gross energy intakes were depressed in phases $\mathrm{I}, 2$ and $2 \mathrm{~A}$ for both RM treatments, an observation that raises a question on the palatability of $\mathrm{RM}$ at this high dietary level. Low intakes of diets containing RM at high levels have been observed previously (Bowland et al. 1965). $^{2}$ )

The growth pattern for rats on the four treatments, as illustrated in Fig. I, and the PER values may be compared with results available for $\operatorname{td}(\mathrm{N})$, NPU and BV of the test diets as estimated in phases 1 and 2 (Table 3 ). Rate of gain of rats fed the RM diets was lower than for those fed the SM or CS diets. However, PER values were between I.9 and $2 \cdot 4$ and did not differ significantly between treatments.

There was a positive relationship between the various indices and growth although the relative differences between treatments differed substantially. In phase $\mathrm{I}, \mathrm{BV}$ was not significantly lower in the $\mathrm{RM}(\mathrm{S})$ and $\mathrm{RM}(\mathrm{PS})$ treatments $\left(83^{\circ} \circ \pm 7^{\circ} 9\right.$ and $\left.84^{\cdot} \pm \pm 5^{\circ} 6\right)$ than in the CS groups. However, the NPU values for both RM treatments were on average $14 \%$ lower than those for SM and CS. In phase 2, the NPU values were lower for the RM treatments than for the SM and CS treatments whereas Bv was similar for all treatments. NPU was superior to BV as an indicator of major differences in growth performance.

Widely varying Bv have been reported for casein. As an example of a recent study, Gangal \& Magar ( 1967 ) reported Bv for casein in the mature adult rat to be $88 \cdot 2 \pm 4 \cdot 8$ as compared with $96 \cdot 7 \pm \mathrm{r} \cdot 5$ recorded in this study. The value reported by the same authors for $\operatorname{td}(\mathrm{N})$ was $90^{\circ} 4 \pm 0.44$ and the calculated NPU was $80^{\circ} 2$. These values are all lower than those obtained in the present study.

The higher indices with mature rats in phase 2 as compared with those for weanling rats in phase I may be explained on the basis of the nature and availability of the carbohydrate fraction of the diets. The weanling rat probably could not efficiently utilize starch or other branched or complex polysaccharides because of the undeveloped enzyme system in its digestive tract (Kon \& Cowie, 196I). Maize starch constituted $3^{2-48 \%}$ of the diets. The level of starch could also explain the superiority of SM over $\mathrm{CS}$ diets as measured by $\mathbf{B V}$ in phase $\mathrm{I}$. The daily gross energy intakes were $34^{\circ} 2$ and $33.5 \mathrm{kcal} / \mathrm{rat}$ with the SM and CS diets, but the CS diet contained $10 \%$ more of maize starch (Table I). The SM and CS diets both contained $30 \%$ sucrose. It is also possible 
that differences in the amino acid requirements of the rats at the two ages could explain at least some of the differences between indices of growth.

The inferior growth response obtained for the RM treatments under the experimental conditions (Fig. I) is probably associated with several factors. Amino acid analyses of the two samples of RM conducted in this laboratory (Clandinin, 1967), and shown in Table 2 indicate that the lysine, methionine, phenylalanine, valine and isoleucine contents of the RM diets were critically lower (less than $80 \%$ ) than the minimum growth requirement of the rat. The SM diet was low in lysine, methionine and valine and the CS diet was low in methionine. Phenylalanine was low in the RM diets even when adjusted for the tyrosine present, representing only $68 \%$ of the requirement; phenylalanine appears to have been the most limiting amino acid in comparison with the SM and CS diets. Isoleucine was the second most limiting essential amino acid in the RM diets. The RM diets met only $77 \%$ of the isoleucine requirement whereas the SM and CS diets exceeded this requirement. The nutritional indices (Table 3 ) suggest that amino acid requirements for optimum $\mathrm{N}$ retention when diets containing 10\% protein are fed may not be the same as those for optimum gain in weight.

The crude fibre content of RM diets and the nature of this fibre may have influenced the growth response in this study, even though the addition of cellulose to the proteinfree diets had no effect on performance. It is possible that in RM the lignification is arranged and distributed in such a way that its protein is trapped by the fibrous material and therefore limited in its availability. To meet the desired 10\% protein level in the diets, the RMI content of the experimental diets (Table I) was $27 \%$, a high level in a diet for monogastric species (Bowland et al. 1965).

Evidence for the goitrogenic effect of rapeseed meal is reported by Kennedy \& Purves (I94I) and Hussar \& Bowland (1959) for rats and by Clandinin, Renner \& Robblee (I959) for the chick. The presence of goitrogenic principles in RM has been confirmed in this study. The high values for thyroid fresh weights from rats fed RM are in excellent agreement with those reported by Kennedy \& Purves (I94I). As shown in Table 5, all rats fed the RM diets had increased ratios of thyroid gland weight to metabolic body size. This was so for the additional mature rats in phase $2 \mathrm{~A}$ although these rats had been fed the RM diets for only Io days. Kennedy \& Purves (I94I) state on the basis of their experiments with the rat, that the thyroid rapidly reaches a state of physiological equilibrium and retains this equilibrium at increased body-weights.

The higher moisture and protein contents of the rat carcasses in the RM treatments suggest that the carcasses from rats fed diets containing RM were leaner than those fed diets with SM or CS. This observation is not unexpected considering the overall lower gross energy intake by the rats fed RM and, as a consequence of this lower intake, the mobilization of body depot fat to cover part of the energy requirements of the rats.

\section{Metabolic faecal $N$}

Faecal $\mathrm{N}$ loss during the protein-free period varied substantially depending on the age of the rat, with mean daily values for all 'protein-free' diets combined of $98 \cdot 0 \pm$ 
$9 \cdot 3 \mathrm{mg} \mathrm{N} / \mathrm{kg}$ body-weight (phase I), $37 \cdot 9 \pm 7 \cdot 2 \mathrm{mg} \mathrm{N} / \mathrm{kg}$ body-weight (phase 2 ) and $56 \cdot \mathrm{I} \pm 5.4 \mathrm{mg} \mathrm{N} / \mathrm{kg}$ body-weight (phase $2 \mathrm{~A}$ ) (Table 4). The $\mathrm{m}(\mathrm{N})$ excretion on the protein-free diet accounted for $27.9 \%$ of the total daily urinary plus faecal $\mathrm{N}$ loss in the weanling rat and $67 \cdot 3 \%$ for rats at maturity (phases 2 and $2 \mathrm{~A}$ ). The value obtained with the adult rat by Ashworth \& Cowgill (1938) accounts for only $26 \cdot 3 \%$ of the total urinary and faecal $\mathrm{N}$ excretion on a protein-free diet. Mitchell (1924) found that mature rats of approximately $160 \mathrm{~g}$ body-weight excrete $\mathrm{II} \cdot 3 \mathrm{mg} \mathrm{N} /$ day on a proteinfree diet or $72.9 \mathrm{mg} / \mathrm{kg}$ body-weight. Blaxter \& Wood (I95 I $a$ ) reported $\mathrm{N}$ excretion of $2 \cdot 10 \mathrm{~g} /$ day or $55 \mathrm{mg} / \mathrm{kg}$ body-weight when feeding a $\mathrm{N}$-free diet resembling milk to a $35^{-40} \mathrm{~kg}$ calf. Fomon et al. (1965) presented results of a series of N-balance experiments with $4-6$ months old infants fed a protein-deficient diet providing only $0.16-0.19 \mathrm{~g}$ protein/kg per day. It was shown that the faecal $\mathrm{N}$ excretion of these infants was influenced by the protein intake received before the feeding of the proteindeficient diet. The values reported were 32.5 and $20 \mathrm{mg} \mathrm{N} / \mathrm{kg}$ per day when previous protein intakes were $4.5 \mathrm{~g}$ and $2.5 \mathrm{~g} / \mathrm{kg}$ per day, respectively. Similar results were reported with children $3-8$ years of age. The figures quoted above are in good agreement with our results.

The observations regarding the influence of previous treatment on faecal $\mathrm{N}$ excretion in experiments by Fomon et al. $\left(196_{5}\right)$ with the human infant and Blaxter $\&$ Wood ( $195 \mathrm{I} a$ ) with the calf are well illustrated in the present study with the weanling rat. The weanling rat excreted $98 \cdot 0 \pm 9 \cdot 3 \mathrm{mg} \mathrm{N} / \mathrm{kg}$ body-weight during the protein-free period when maintained previously on a high protein intake while suckling its mother. Based on rat's milk containing $12 \%$ protein and approximately $25 \%$ total solids, the milk is equivalent to a concentrate diet containing $48 \%$ high-quality protein in the dry matter (Kon \& Cowie, I96r). The rats, when brought to maturity on a much lower dietary protein intake (10\% protein in the diet) reduced their $\mathrm{m}(\mathrm{N})$ excretion to a value of $37^{\circ} 9 \pm 7.2 \mathrm{mg} \mathrm{N} / \mathrm{kg}$ body-weight when placed on a protein-free diet. At approximately the same age and body-weight range, the additional group of mature rats, reared on a stock diet of $2 \mathrm{r}-22 \%$ protein, had an $\mathrm{m}(\mathrm{N})$ excretion of $56 \cdot \mathrm{I} \pm 5.4 \mathrm{mg}$ $\mathrm{N} / \mathrm{kg}$ body-weight.

Young \& Schrimshaw (1968), in an investigation on the endogenous $\mathrm{N}$ metabolism of young human adults, reported mean daily values for $\mathrm{m}(\mathrm{N})$ losses ranging from 5.8 to $\mathrm{x} 3.8 \mathrm{mg} \mathrm{N} / \mathrm{kg}$ body-weight, accounting for approximately $20 \%$ of the combined urinary and faecal $\mathrm{N}$ loss. Their results with the adult human subject are not in agreement with those obtained with the weanling or mature rat.

The adjustment of the protein-free diets to a different cellulose level did not influence the metabolic faecal $\mathrm{N}$ excretion. A lignin-like compound would probably have been more appropriate for use in this instance. The $\mathrm{N}$ excretion was related to the dry-matter intake and a value of $0.08 \mathrm{~g} \mathrm{~N} / 100 \mathrm{~g}$ dry-matter ingested was obtained for the weanling and the mature rat. The above value differs considerably from the value of $0.45 \mathrm{~g} \mathrm{~N} / 100 \mathrm{~g}$ dry-matter intake which represents the value obtained by Blaxter $\&$ Wood ( $195 \mathrm{I} a$ ) for the young calf and a quoted value for the adult ruminant based on reports by other workers. A recalculation of the values presented by Young \& Scrimshaw (r968) and Fomon et al. (1965) shows that the metabolic faecal $\mathrm{N}$ excretion is 
about $0.11-0.12 \mathrm{~g} / 100 \mathrm{~g}$ dry-matter intake for the young human adult and the child. These and our observations support the view that species differences established early in life remain unchanged thereafter.

If satisfactory methods can be devised to remove the hull from rapeseed meal, and hence lower the fibre content, and if the goitrogens can be removed genetically or chemically, it is probable that this meal would be markedly improved as a protein source for animal and human nutrition. With present research in progress on rapeseed meal, such modifications of the meal appear to be feasible in the near future.

One of us (N. J. D.) was in receipt of a postdoctorate fellowship under a grant to J. P. B. from the National Research Council of Canada. The authors thank Dr R. T. Hardin for his assistance with the statistical analyses and interpretation of the results. The technical assistance of P. Larsen is gratefully acknowledged.

\section{REFERENCES}

Allison, J. B. \& Wannemacher, R. W. Jr (1965). Am. F. clin. Nutr. 16, 445.

Ashworth, J. S. \& Cowgill, G. R. (1938). F. Nutr. 15, 73.

Astwood, E. B., Greer, M. A. \& Ettlinger, M. G. (I949). F. biol. Chem. 181, I2 1.

Blaxter, K. L. \& Wood, W. A. (195 I $a$ ) Br. F. Nutr. 5, I I.

Blaxter, K. L. \& Wood, W. A. (195 I $b$ ) Br. F. Nutr. 5, 55.

Block, R. J. \& Weiss, A. B. (1956). Amino Acid Handbook. Springfield, Ill.: C. C. Thomas.

Boas-Fixsen, M. A. (1935). Nutr. Abstr. Rev. 4, 447.

Bowland, J. P., Clandinin, D. R. \& Wetter, L. R. (editors) (1965). Publs Can. Dep. Agric. no. I257. Ottawa, Canada: Queen's Printer.

Campbell, J. A. (1961). Nutrition Document R 10/Add. 37. WHO/FAO/UNICEF. PAG, N.Y. International Nutrition Conference.

Clandinin, D. R. (1967). Poult. Sci. 46, 596.

Clandinin, D. R., Renner, R. \& Robblee, A. R. (1959). Poult. Sci. 38, r367.

Fomon, S. J., DeMaeyer, E. M. \& Owen, G. M. (1965). F. Nutr. 85, 235.

Gangal, S. V. \& Magar, N. G. (1967). Br. F. Nutr. 21, 1.

Hussar, N. \& Bowland, J. P. (1959). Can. F. Anim. Sci. 39, 84.

Kennedy, T. H. \& Purves, H. D. (I941). Br. J. exp. Path. 22, 24 I.

Kon, S. K. \& Cowie, A. T. (editors) (1961). Milk: The Mammary Gland and its Secretions. Vol. 2., p. 305 . [S. K. Kon and A. T. Cowie, editors.] London: Academic Press Inc.

Mitchell, H. H. (1924). F. biol. Chem. 58, 873 .

Munro, H. N. (1964). In Mammalian Protein Metabolism. Vol. I, p. $3^{81}$. [H. N. Munro and J. B. Allison, editors.] New York: Academic Press Inc.

National Research Council (1962). Publs natn. Res. Coun., Wash. no. 990.

Wetter, L. R. (1955). Can. F. Biochem Physiol, 33, 980.

Young, V. R. \& Scrimshaw, N. S. (1968). Br. F. Nutr. 22, 9. 